\title{
Fibromyalgia: is there association \\ between balance and pain? a pilot study
}

Fibromialgia: existe associação entre equilíbrio e dor? um estudo piloto

Fibromialgia: ¿hay una asociación entre el equilibrio y el dolor? un estudio piloto

Adriana de Sousa do Espírito Santo', Pamela Cristina Mango', Ana Assumpção', Juliana Ferreira Sauer', Amélia Pasqual Marques ${ }^{1}$

\begin{abstract}
I Studies of balance and risk factors for falling typically focus on the elderly population or on individuals with musculoskeletal pain. Although fibromyalgia is associated with intrinsic factors that predispose to falls (pain, depression, fatigue), few studies have researched balance and falls in this syndrome. The aim of this study was to verify the association between balance, balance self-efficacy and pain in women with and without fibromyalgia, and verify the association between Berg Balance Scale and Activities-specific Balance Confidence Scale (ABC Scale). The sample consisted of 48 women aged between 40 and 59 years, divided into two groups: Fibromyalgia group ( $\mathrm{n}=22$ ) and Control group ( $\mathrm{n}=26$ ) with asymptomatic people. Balance was assessed by Berg Balance Scale, balance self-efficacy by the ABC Scale and pain by the visual analog scale. Mean scores for pain, Berg and ABC Scale were $5.4 \mathrm{~cm}$ (SD 2.6), 55 (interquartile range 54-56), and 54.6 (SD 26.6) respectively for Fibromyalgia group, and $0 \mathrm{~cm}, 56$ (interquartile range 55-56), and 89.4 (SD 14.4) respectively for Control group. Statistically significant differences were found in balance on comparing both groups ( $p=0.000$ for Berg Balance Scale and 0.009 for ABC Scale) with lower values for Fibromyalgia group. In Fibromyalgia group, pain was negatively correlated with balance $(r=-0.48, p=0.020)$ and balance self-efficacy $\left(r_{s}=-0.56\right.$, $p=0.006)$. Correlation between Berg Balance Scale and $A B C$ Scale was found only in the Fibromyalgia group $\left(r_{s}=0.55, p=0.007\right)$. There are associations between poor balance and pain, and poor balance and decreased
\end{abstract}

balance self-efficacy in women with fibromyalgia. There is an association between scales in the Fibromyalgia group.

Keywords I Pain; Fibromyalgia; Postural Balance; Accidental Falls; Fear; Efficacy.

RESUMO I O estudo das quedas e déficit de equilíbrio tem privilegiado os idosos e pessoas portadoras de dor musculoesquelética. Apesar de a fibromialgia apresentar fatores intrínsecos que podem estar associados às quedas (dor, depressão, fadiga), poucos tem estudado equilíbrio e quedas nesta síndrome. O objetivo deste estudo foi verificar a associação entre equilíbrio, autoconfiança no equilíbrio e dor em mulheres com e sem fibromialgia e verificar a associação entre as escalas: escala de equilíbrio de Berg e Activities-specific Balance Confidence scale (escala $A B C$ ). Participaram do estudo 48 mulheres entre 40-59 anos, sendo 22 com fibromialgia (GF) e 26 assintomáticas que constituíram o grupo controle (GC). O equilíbrio foi avaliado através da "Berg Balance Scale" (escala Berg), a auto confiança no equilíbrio pela "Activities-specific Balance Confidence scale" (escala ABC) e a dor pela Escala Visual Analógica (EVA). A média dos escores para dor, escala de Berg e ABC foram respectivamente 5,4 cm (DP 2,6), 55 (IQ 54-56) e 54.6 (DP 26,6) para o grupo Fibromialgia e zero cm, 56 (IQ 55-56) e 89.4 (DP 14,4) respectivamente para o grupo Controle. Os resultados das escalas de equilíbrio mostraram diferença estatisticamente significativa entre os grupos $(p=0,000$ para Berg e 0,009 para escala $A B C$ ) com valores 
menores para o grupo Fibromialgia. Houve correlação negativa entre dor e escala de Berg $(r=-0,48, p=0,020)$ e escala $A B C$ $\left(r_{s}=-0,56, p=0,006\right)$ no grupo Fibromialgia. Houve correlação entre as escalas somente no $\mathrm{GF}\left(r_{\mathrm{s}}=0,55, \mathrm{p}=0,007\right)$. Existe associação entre falta de equilíbrio e dor e entre falta de equilíbrio e auto confiança no equilíbrio em mulheres com fibromialgia. Existe uma associação entre as escalas no grupo Fibromialgia.

Descritores | Dor; Fibromialgia; Equilibrio Postural; Quedas Acidentais, Medo, Eficácia.

RESUMEN I El estudio de las caídas y déficit de equilibrio ha privilegiado a los mayores y las personas portadoras de dolor musculoesquelético. Aunque la fibromialgia presente factores intrínsecos que pueden estar asociados con las caídas (el dolor, la depresión, la fatiga), pocos han estudiado el equilibrio y la caída en este síndrome. El objetivo de este estudio fue verificar la asociación entre el equilibriol, la autoconfianza en el equilibrio y el dolor en mujeres con y sin fibromialgia y verificar la asociación entre las escalas: de equilibrio de Berg y la Activities-specific Balance Confidence scale (escala ABC). Participaron del estudio 48 mujeres con edades entre 40-59 años, siendo 22 con fibromialgia (GF) y 26 asintomáticas que constituyeron el grupo de control (GC). Se ha evaluado el equilibrio a través de la "Berg Balance Scale" (escala de Berg), la autoconfianza en el equilibrio por la "Activitiesspecific Balance Confidence scale (escala ABC)" y el dolor por la Escala Visual Analógica (EVA). El promedio de las puntuaciones de dolor, escala Berg y $A B C$ fueron respectivamente $5.4 \mathrm{~cm}$ (DE 2.6), 55 (IQ 54-56) y 54.6 (DE 26.6) para el grupo Fibromialgia y cero cm, 56 (IQ 55-56 ) y 89.4 (DE 14.4 ) respectivamente para el grupo de control. Los resultados de las escalas de equilibrio mostraron diferencia estadísticamente significativa entre los grupos ( $p=0.000$ para Berg y 0. 009 para la escala ABC) con valores menores para el grupo Fibromialgia. Hubo una correlación negativa entre el dolor y la escala de Berg $\left(r_{s}=-0,48, p=0,020\right)$ y la escala $A B C\left(r_{s}=-0,56, p=0,006\right)$ en el grupo Fibromialgia. Hubo una correlación entre las escalas sólo en el GF ( $r_{s}=0.55$, p=0,007). Existe una asociación entre la falta de equilibrio y el dolor y entre la falta de equilibrio y autoconfianza en el equilibrio en mujeres con fibromialgia. Existe una asociación entre las escalas del grupo Fibromialgia.

Palabras clave I Dolor; Fibromialgia; Equilibrio Postural; Caídas Accidentales; Miedo; Eficacia.

\section{INTRODUCTION}

Fibromyalgia (FM) is a rheumatologic syndrome characterized by chronic and diffused musculoskeletal pain, associated with the presence of multiple tender points over the body. Tenderness may be identified when a pressure of approximately $4 \mathrm{kgf}^{1}$ by digital pressure or $2,6 \mathrm{~kg} / \mathrm{cm}^{2}$ is applied by algometer ${ }^{2}$. In 2010, simple, practical criteria for clinical diagnosis of fibromyalgia suitable for use in primary and specialty care, do not require a tender point examination and provide a severity scale for characteristic fibromyalgia symptoms were developed ${ }^{3}$.

Other symptoms include fatigue, sleep problems, morning stiffness and psychological symptoms such as anxiety, stress, depression ${ }^{4,5}$ and dyspnea ${ }^{6}$. The association of these symptoms impacts the functionality of these patients ${ }^{7}$. Fibromyalgia is a persistent and potentially debilitating disorder that can have a devastating effect on the quality of life, impairing the patient's ability to work and participate in everyday activities, as well as affecting relationships with family, friends and employers ${ }^{8}$.

Diffuse pain may impair balance contributing to increase the risk of falls. This has been reported in elderly women, and risk of fall increased by $60 \%$ in those with chronic pain ${ }^{9}$. Brand et al. who had observed that 49\% of rheumatic patients reported having suffered a fall and $25.2 \%$ had two or more falls over 12 months, suggested that the musculoskeletal problems have been identified as risk factor of fall ${ }^{10}$. Studies indicate that female gender shows higher prevalence and risk of falls ${ }^{11,12}$. Some authors have identified other predictive factors, including balance, time to react, cognitive state, presence of urinary incontinence ${ }^{12}$, age, presence of chronic pain, and severity of comorbid diseases ${ }^{13,14}$. Another important independent predictive factor is fear of falling ${ }^{15-19}$.

Individuals with FM may be at increased risk for falls, since they share some risk factors (pain and rheumatologic disease). FM is associated with balance problems and increased fall frequency ${ }^{20-22}$. Russek and Fulk in a pilot study assessed postural control and balance self-efficacy in people with $\mathrm{FM}^{22}$ and Jones et al. found that FM may affect peripheral and/or central mechanisms of postural control ${ }^{20}$.

Some studies assessed the association between balance and pain in patients with FM. The aim of this study was to verify the association between balance, self-efficacy and pain in women with and without fibromyalgia and verify the association between Berg Balance Scale and Activities-specific Balance Confidence scale (ABC scale). 


\section{METHODOLOGY}

\section{Sample}

Our sample consists of 48 adult women aged between 40 and 59 years, divided into two groups: Fibromyalgia Group (FG) (n=22) and Control Group (CG) $(n=26)$. FG constituted participants with the following characteristics: diagnosis of FM by a rheumatologist, fulfilment of the American College of Rheumatology 1990 criteria for the classification of fibromyalgia, and referral of the FM outpatient clinic of the Physical Therapy course. CG constituted asymptomatic volunteers recruited by posters placed around the university campus and invitation to patients' companions. We excluded individuals with comorbidities that could further compromise the balance, such as diabetes, neurological diseases (e.g. stroke, Parkinson's disease), other musculoskeletal disorders (severe osteoarthritis, surgeries of the hip and rheumatoid arthritis). We also excluded individuals who were treated for traumatic injuries in the past six months, and people who practice regular physical activity. Finally, we excluded individuals with non-corrected auditory or visual disabilities, and with deficits of cognition or memory (dementia). The sample size was calculated to detect a $20 \%$ difference between groups in pain, with power of $80 \%$ and significance level at 5\%, resulting in 17 participants per group. All recruited participants completed the study and there was no missing data. The ethics committee for the analysis of research approved the study. All participants were instructed on the purpose of the study and provided written consent.

\section{Procedures}

The study was conducted in the Department of Physical, Speech and Occupational Therapy of the School of Medicine at the University of Sao Paulo, throughout the year of 2009 .

Full evaluation of the participants were performed by a previously trained physiotherapist and lasted for 60 minutes. All participants were assessed individually for their demographics and clinical history, and were asked the number of falls over the last six months. The validated Brazilian-Portuguese version of the Fibromyalgia Impact Questionnaire (FIQ ${ }^{23,24}$ was used to assess FG. This questionnaire measures symptoms of FM, as well as its impact on the quality of life.
FIQ contains 19 questions related to ten items: physical function, work missed, well-being, capacity to work, pain, fatigue, morning stiffness, sleep disturbance, anxiety and depression. Higher scores indicate a greater impact of fibromyalgia on the quality of life.

\section{Assessment of Pain}

Pain intensity during the evaluation was measured by a visual analog scale $(\mathrm{VAS})^{25}$, ranging from 0 to $10 \mathrm{~cm}$; higher scores correspond to more severe pain ${ }^{26}$.

\section{Assessment of Balance and Balance Self-Efficacy}

Balance was measured using the Berg Balance Scale $(\mathrm{BBS})^{27}$. BBS was validated in Portuguese by Miyamoto $^{28}$. It assesses balance performance using 14 tests developed to simulate daily activities. Each item receives scores from 0 to 4 , where 0 means total incapacity, and 4 corresponds to no limitation (activity performed without assistance, with confidence and in proper time). The highest possible score is 56 . Higher scores suggest better equilibrium and functional independence for daily normal activities.

Self-efficacy was assessed with the ABC Scale ${ }^{29}$. It has a 16-item questionnaire that measures functional activities (such as reaching objects placed at the level of the eyes). Individuals are asked to report their confidence in performing activities without losing their balance. Scores vary from $0 \%$ (no confidence at all) to $100 \%$ (totally confident) ${ }^{30}$. Total scores are the average of individual scores. Lower scores suggest decreased self-efficacy and high risk of falls. Lajoie ${ }^{13}$ found that $\mathrm{ABC}$ Scale has a sensitivity of $84.4 \%$ and specificity of $87.5 \%$ when the cut-off of $67 \%$ is used for predicting risk of falls in the elderly.

\section{Data Analysis}

Data were summarized using descriptive statistics. Normality was tested using the Shapiro Wilk test. Variables with normal distribution were compared using the $\mathrm{T}$ test. Variables with non-normal distribution were compared through the non-parametric Mann-Whitney U test.

For correlation analysis, Pearson tests were used for variables with normal distribution, and the Spearman $\left(\mathrm{r}_{\mathrm{s}}\right)$ test for non-parametric variables. According to Fleiss, the r value may be interpreted as follows: excellent 
correlation when $r>0.75$, moderate when $0.4<r<0.75$, and week when $r<0.4^{31}$. The significance level adopted was $5 \%$. The statistical tests were performed with the software, Statistica8.

\section{RESULTS}

Table 1 presents the mean and standard deviation (SD) of demographic data. Statistically significant differences were found for weight and body mass index $(B M I) \quad(p<0.05)$. No significant differences were seen in age and height. The total number of falls in FG was double $(n=18)$ that of CG $(n=9)$. The percentage of falls over the past six months was about $66 \%$ for FG, while for CG it was 33\%. During assessment, participants with FM presented a mean VAS score of $5.4 \mathrm{~cm}$ (SD 2.6), while those with CG had no pain.

Table1. Social demographic and clinical features of patients in Fibromyolgia group and Control group and Fibromyalgia Impact Questionnaire for patients with Fibromyalgia

\begin{tabular}{|c|c|c|c|}
\hline Variable & $\begin{array}{l}F G(n=22) \\
M e a n \pm S D\end{array}$ & $\begin{array}{l}C G(n=26) \\
M e a n \pm S D\end{array}$ & p-value \\
\hline Age (years) & $48 \pm 4.0$ & $47 \pm 5.0$ & 0.48 \\
\hline Height (m) & $1.56 \pm 0.06$ & $1.58 \pm 0.06$ & 0.41 \\
\hline Weight (kg) & $64.7 \pm 9.3$ & $58.7 \pm 5.2$ & 0. $007^{\star}$ \\
\hline $\mathrm{BMI}^{\star \star}\left(\mathrm{kg} / \mathrm{m}^{2}\right)$ & $26.3 \pm 3.4$ & $23.4 \pm 2.0$ & $0.0008^{*}$ \\
\hline Pain $(\mathrm{cm})$ & $5.4 \pm 2.6$ & 0 & \\
\hline Falls (n) & 18 & 9 & \\
\hline \multicolumn{4}{|l|}{$\mathrm{FIQ}$} \\
\hline Physical function & $10.5(5.9)$ & & \\
\hline Well-being (days) & 1 & & \\
\hline Work missed (days) & 1 & & \\
\hline Capacity to work (cm) & $7.5 \pm 2.1$ & & \\
\hline Pain $(\mathrm{cm})$ & $8.1 \pm 1.7$ & & \\
\hline Fatigue $(\mathrm{cm})$ & $8.4 \pm 1.6$ & & \\
\hline Morning tiredness (cm) & $6.7 \pm 3.1$ & & \\
\hline Stiffness (cm) & $7.3 \pm 2.8$ & & \\
\hline Anxiety $(\mathrm{cm})$ & $6.5 \pm 3.2$ & & \\
\hline Depression (cm) & $5.8 \pm 3.5$ & & \\
\hline Total FIQ & $5.9 \pm 2.9$ & & \\
\hline
\end{tabular}

*p<0.05; SD: standard deviation; BMI: body mass index; FIQ: Fibromyalgia Impact Questionnaire; FG: Fibromyalgia group; CG: Control group

Table 2. Values for $A B C$ and Berg Scales in both groups

\begin{tabular}{lccc} 
Variables & FG $(n=22)$ & CG (n=26) & p-value \\
$\begin{array}{l}\text { Balance self-efficacy } \\
\quad(\text { Mean } \pm \text { SD) }\end{array}$ & $54.6 \pm 26.6$ & $89.4 \pm 14.4$ & $0.000001^{*}$ \\
$\begin{array}{l}\text { Balance } \\
\quad \begin{array}{l}\text { Median } \\
(\text { IQR })\end{array}\end{array}$ & 55 & 56 & \\
\hline (54/56) & $(55 / 56)$ & $0.009^{*}$
\end{tabular}

*p<0.05; SD: standard deviation; BMI: body mass index; IQR: Interquartile range; FG: Fibromyalgia group; CG: Control group
Results of FIQ of FG are displayed in Table 1. Quality of life was impaired, with high mean values for pain, fatigue and stiffness. Participants reported feeling well on average of one day per week. They had reduced performance for doing tasks, although absenteeism from work was rare.

Table 2 displays the results for the balance and balance self-efficacy. The values were significantly lower in $\mathrm{FG}$, in contrast to $\mathrm{CG}(\mathrm{p}<0.005)$.

Figure 1 shows the association between balance and pain in individuals with fibromyalgia during the time of assessment. There is moderate negative correlation $\left(r_{s}=-0.48, p=0.02\right)$ in FG.

Figure 2 shows the association between pain and balance self-confidence during the time of assessment in individuals with fibromyalgia. Moderate negative correlation between variables $\left(\mathrm{r}_{\mathrm{s}}=-0.56, \mathrm{p}=0.006\right)$.

Moderate positive correlation between BBS and ABC Scales was found in Fibromyalgia Group, $\left(r_{s}=0.55\right.$ and $p=0.007)$ but not in Control Group $\left(r_{s}=0.28\right.$ and $\mathrm{p}=0.15)($ Figure 3).

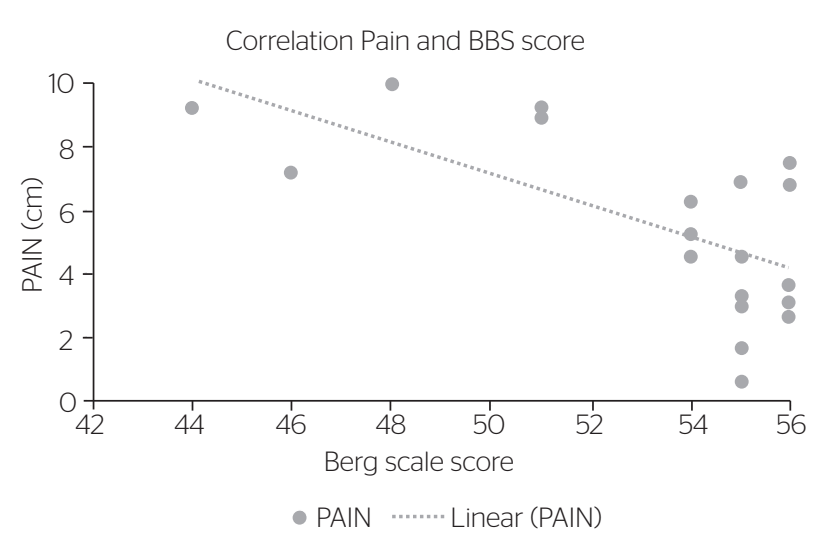

Figure 1. Association between pain and balance in individuals with fibromyalgia

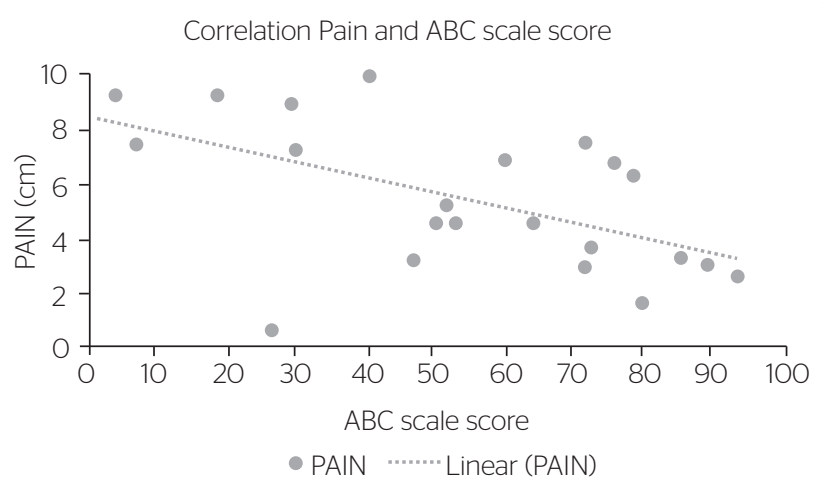

Figure 2. Association between pain and balance self-efficacy in individuals with fibromyalgia 


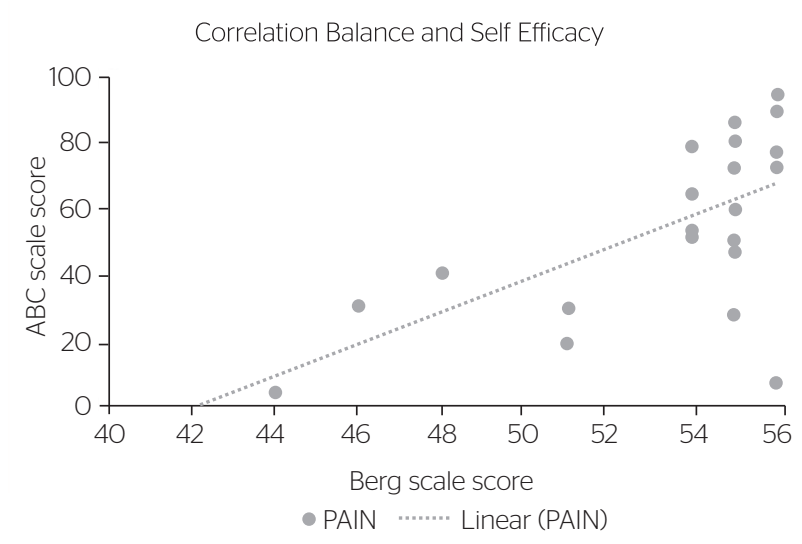

Figure 3. Association between Berg Scale score and Activities-specific Balance Confidence Scale in individuals with fibromyalgia

\section{DISCUSSION}

The present study showed that women with FM had moderate pain, reduced balance self-efficacy for performing activities of daily life and decreased functional balance, and the values from both scales were significantly lower in FG in contrast to $\mathrm{CG}$, which may increase risk for falls.

Patients with FM had lower scores in BBS; nine of them had scores between 54 and 44, responding for 14 of the 18 falls reported by patients with FM. In CG, only two women had score of 54; the remaining had maximum values. According to Shumway-Cook and Woollacott ${ }^{32}$, in the range from 56 to 54 , each point decreased in the BBS responds for an increased 3 to $4 \%$ in the risk of falls; however, in the range of 54 to 46, single point variations are associated with a 6 to $8 \%$ risk change. Some women with FM had an increase in the risk of falls of up to $60 \%$. Differences in the BBS scores for women with FM and controls were statistically significant in the present study ${ }^{27,28}$.

Jones et al. ${ }^{20,21}$ found higher scores for ABC scale $(73.23,81.24)$ in Fibromyalgia Group. In contrast, the present study shows lower values (54.6), suggesting that the participants with FM have greater fear of falling compared to those in CG (89.4). Kressig et al. ${ }^{18}$ found, in the elderly, mean ABC Scale score of 51.8, a similar result to ours'. Accordingly, we found that individuals with FM had both reduced balance self-efficacy and impairment. Jones et al. ${ }^{20}$ who assessed balance performance with the Balance Evaluation-System Test (BES Test) also describe a similar finding.

Armstrong et al. ${ }^{33}$ report that patients with rheumatologic diseases had increased risk of falls because of joint problems in the lower limbs, resulting in decreased mobility, impaired balance and decreased postural stability. In a study that enrolled individuals with rheumatoid arthritis, the authors reported that presence of pain and weakness was associated with falls over the past year in one-third of the sample. Since rheumatologic disorders are associated with falls, musculoskeletal disorders may be a risk factor as well. Brand et al. ${ }^{10}$ found that fear of falling is also commonly reported by individuals with rheumatologic diseases; we found moderate negative association between scores in the VAS and ABC Scale, suggesting that balance self-efficacy is negatively influenced by pain severity. Jones et al. ${ }^{20}$ found correlation between pain and ABC $(r-0.55, \mathrm{p}<0.01)$, but in another study by them ${ }^{21}$, pain was not a predictive factor for fall.

Moderate negative association between pain and functional balance was found in agreement with findings of Leveille and colleagues ${ }^{9}$, who found that pain increased the risk of falls, widespread pain and chronic pain contribute to disabilities, and both types of pain are associated with greater risk of fall in older women $^{34,35}$. Foley et al. ${ }^{36}$ found that pain, age, stiffness and functional capacity were also correlated with risk of falls among men and women in the age range of 50 to 80 years. However, when they adjusted for these potentially confounding factors, pain remained a strong independent risk factor for falls. Jones et al. ${ }^{21}$ found that pain was not a predictive factor for fall. However, Leveille and colleagues ${ }^{9}$ discuss that pathway pain that leads to fall, likely includes a psychological and physiological factors (for example: pain alters reflex muscle inhibition leading to prejudice to protective response to fall. People who have chronic pain reduce their activities and experience decline in strength and mobility. Chronic pain may interfere with attention that is linked with ability to maintain postural control.) All symptoms of fibromyalgia, such as pain, stiffness, functional capacity and fear of fall, may have contributed to the decreased balance in the samples of the present study.

For individuals with FM, moderate positive correlation ( $r_{s}=0.55$ and $\left.p=0.007\right)$ was found between the BBS and ABC Scales. Hatch and colleagues ${ }^{15}$ also found association between balance self-efficacy and objective tests measuring balance, suggesting that individuals with low confidence may have real impairments in postural control. Brand et al. ${ }^{10}$ observed a moderate association between increased fear of falling and lower Falls Efficacy Scale score. Balance test was moderately related to balance self-efficacy, as measured 
by the $\mathrm{ABC}$, in the subjects in study of Russek and Fulk $^{22}$. We did not find significant correlation in the Control group.

These findings suggest that FM reduces balance and may be associated with increased risk of falls, which contributes to impairment in the quality of life of these patients, as well as to the costs of this disorder to the health system (aggregated costs of the falls) ${ }^{37}$.

Accordingly, it is important that patients with FM are adequately instructed to prevent falls. Additionally, as a part of the treatment, they should be instructed to exercise to improve their balance.

\section{LIMITATIONS TO THE STUDY}

The limitations to the study were the small sample size and the use only of scales to assess balance.

\section{CONCLUSION}

There are associations between poor balance with pain and decreased self-efficacy in women with fibromyalgia.

\section{REFERENCES}

1. Wolfe F, Smythe HA, Yunus MB, Bennett RM, Bombardier C, Goldenberg DL, et al. The American College of Rheumatology 1990 Criteria for the classification of fibromyalgia. Report of the Multicenter Criteria Committee. Arthritis Rheum. 1990;33(2):160-72.

2. Marques AP, Ferreira EA, Matsutani LA, Pereira CA, Assumpção A. Quantifying pain threshold and quality of life of fibromyalgia patients. Clin Rheumatol. 2005:24(3):266-71.

3. Wolfe F, Clauw DJ, Fitzcharles MA, Goldenberg DL, Katz RS, Mease P, et al. The American College of Rheumatology preliminary diagnostic criteria for fibromyalgia and measurement of symptom severity. Arthritis Care Res (Hoboken). 2010;62(5):600-10.

4. White KP, Nielson WR, Harth M, Ostbye T, Speechley M. Chronic widespread musculoskeletal pain with or without fibromyalgia: psychological distress in a representative community adult sample. J Rheumatol. 2002;29(3):588-94.

5. Davis MC, AJ Zautra, Reich JW. Vulnerability to stress among women in chronic pain from fibromyalgia and osteoarthritis. Ann Behav Med. 2001;23(3):215-26.

6. Weiss DJ, Kreck T, Albert R.K. Dyspnea resulting from fibromyalgia. Chest. 1998:113(1):246-9.
7. Goldberg DLB, Arnold LM, Glass JM, Clauw DJ. Understanding fibromyalgia and its related disorders. Prim Care Companion J Clin Psychiatry. 2008;10(2):133-44.

8. Arnold LM, Clauw DJ, McCarberg BH. Improving the recognition and diagnosis of fibromyalgia. Mayo Clin Proc. 2011;86(5):457-64.

9. Leveille SG, Bean J, Bandeen-Roche K, Jones R, Hochberg M, Guralnik JM. Musculoskeletal pain and risk for falls in older disabled women living in the community. J Am Geriatr Soc. 2002;50(4):671-8.

10. Brand CA, Lowe A, Morton C. Prevalence, outcome and risk for falling in 155 ambulatory patients with rheumatic disease. APLAR J Reumatol. 2005;8:99-105.

11. Manrique-Espinoza B, Salinas-Rodríguez A, Moreno-Tamayo K, TéllezRojo MM. Functional dependency and falls in elderly living in poverty in Mexico. Salud Publica Mex. 2011;53(1):26-33.

12. Moon SJ, Kim YT, Lee TY, Moon H, Kim MJ, Kim SA, et al. The influence of an overactive bladder on falling: a study of females aged 40 and older in the community. Int Neurourol J. 2011:15(1):41-7.

13. Lajoie Y, Gallagher SP. Predicting falls within the elderly community: comparison of postural sway, reaction time, the Berg balance scaleand the Activities-specific Balance Confidence (ABC) scale for comparing fallers and non-fallers. Arch Gerontol Geriatr. 2004;38(1):11-26.

14. Chen JS, March LM, Schwarz J, Zochling J, Makaroff J, Sitoh YY, et al. A multivariate regression model predicted falls in residents living in intermediate hostel care. J Clin Epidemiol. 2005;58(5):503-8.

15. Hatch J, Gill-Body KM, Portney LG. Determinants of balance confidence in community-dwelling elderly people. Phys Ther. 2003;83(12):1072-9.

16. Davis JR, Campbell AD, Adkin AL, Carpenter MG. The relationship between fear of falling and human postural control. Gait Posture. 2009;29(2):275-9.

17. Lajoie Y, Girard A, Guay M. Comparison of the reaction time, the Berg Scale and the $A B C$ in non-fallers and fallers. Arch Gerontol Geriatr. 2002;35(3):215-25.

18. Kressig RW, Wolf SL, Sattin RW, O'Grady M, Greenspan A, Curns $\mathrm{A}$, et al. Associations of demographic, functional, and behavioral characteristics with activity-related fear of falling among older adults transitioning to frailty. J Am Geriatr Soc. 2001;49(11):1456-62.

19. Parry SW, Steen N, Galloway SR, Kenny RA, Bond J. Falls and confidence related quality of life outcome measures in an older British cohort. Postgrad Med J. 2001;77(904):103-8.

20. Jones KD, Horak FB, Winters-Stone K, Irvine JM, Bennett RM. Fibromyalgia is associated with impaired balance and falls. J Clin Rheumatol. 2009;15(1):16-21.

21. Jones KD, King LA, Mist SD, Bennett RM, Horak FB. Postural control deficits in people with fibromyalgia: a pilot study. Arthritis Res Ther. 2011;13(4):R127.

22. Russek LN, Fulk GD. Pilot study assessing balance in women with fibromyalgia syndrome. Physiother Theory Pract. 2009;25(8):555-65.

23. Burckhardt CS, Clark SR, Bennett RM. The fibromyalgia impact questionnaire: development and validation. J Rheumatol. 1991;18(5):728-33.

24. Marques APS, Assumpção A, Matsutani L A, Lage LV, Pereira CAB. Validação da versão brasileira do Fibromyalgia Impact Questionnaire (FIQ). Rev Bras Reumatol. 2006;46(1):24-31.

25. Katz J, Melzack R. Measurement of pain. Surg Clin North Am. 1999;79(2):231-52.

26. Ciena AP, Rutineia G, Pacini VC, Picanço VV, Magno IMN, Loth EA. Influence of pain intensity on the unidimensional scales responses of pain measurement in an elderly and young adults population. Semina: Ciên Biol Saúde. 2008;29(2):201-12. 
27. Berg KO, Wood-Dauphinee SL, Williams JI, Maki B. Measuring balance in the elderly: validation of an instrument. Can J Public Health. 1992;83 Suppl 2:S7-11.

28. Miyamoto ST, Lombardi Junior I, Berg KO, Ramos LR, Natour J. Brazilian version of the Berg balance scale. Braz J Med Biol Res. 2004:37(9):1411-21.

29. Marques AP, Mendes YC, Taddei U, Pereira CA, Assumpção A. Brazilian-Portuguese translation and cross cultural adaptation of the activities-specific balance confidence (ABC) scale. Braz J Phys Ther. 2013;17(2):170-8.

30. Powell LE, Myers AM. The Activities-specific Balance Confidence (ABC) Scale. J Gerontol A Biol Sci Med Sci. 1995;50A(1):M28-34.

31. Fleiss JL, ed. The design and analysis of clinical experimental. 1986, John Wiley and Sons: New York.

32. MH, S-CAW, ed. Controle Motor- Teorias e aplicações práticas. 2 ed. 2003, Manole: São Paulo.
33. Armstrong C, Swarbrick C, Pye S, O'Neill T. Occurrence and risk factors for falls in rheumatoid arthritis. Ann Rheum Dis. 2005; 64(11):1602-4

34. Leveille SG, Bean J, Ngo L, McMullen W, Guralnik JM. The pathway from musculoskeletal pain to mobility difficulty in older disabled women. Pain. 2007:128(1-2): 69-77.

35. Leveille SG, Jones RN, Kiely DK, Hausdorff JM, Shmerling RH, Guralnik $\mathrm{JM}$, et al. Chronic musculoskeletal pain and the occurrence of falls in an older population. JAMA. 2009;302(20):2214-21.

36. Foley SJ, Lord SR, Srikanth V, Cooley H, Jones G. Falls risk is associated with pain and dysfunction but not radiographic osteoarthritis in older adults: Tasmanian Older Adult Cohort study. Osteoarthritis Cartilage. 2006;14(6):533-9.

37. Moreland JD, Richardson JA, Goldsmith CH, Clase CM. Muscle weakness and falls in older adults: a systematic review and metaanalysis. J Am Geriatr Soc. 2004;52(7):1121-9. 